\title{
Manager's Age, Sustainable Entrepreneurial Orientation and Sustainable Performance: A Conceptual Outlook
}

\author{
Farah Ameer and Naveed R. Khan * \\ Department of Management Sciences, Bahria University, Karachi 75350, Pakistan \\ * Correspondence: naveed.r.khan@gmail.com
}

Received: 24 February 2020; Accepted: 13 April 2020; Published: 15 April 2020

\begin{abstract}
Scholars have investigated the direct linkage between manager's age and sustainable corporate performance, however, the mixed results and conflicting findings on the nature of the relationship demand further explanation through the missing constructs. Therefore, the purpose of this paper is to examine the mediating role of sustainable entrepreneurial orientation in the manager's age and sustainable performance. This study develops a conceptual link by using a dynamic capabilities approach and upper echelon perspective, indicating that younger managers can adopt a more holistic approach towards sustainable practices which can enhance the environmental, social and economic performance of firms. This implies that the relationship between manager's age and sustainable performance can be explained through sustainable entrepreneurial orientation (SEO) which can play a key role in setting organizational direction towards sustainable development and achieving sustainable business performance. This study contributes to the literature by examining the role of SEO in the relationship between the manager's age and sustainable performance. This research will help practitioners recognize the importance of minimizing environmental and social problems generating due to organizational production activities. This will lead to profit generation as well as value creation for nature and the local community.
\end{abstract}

Keywords: manager age; sustainable corporate performance; sustainable entrepreneurial orientation

\section{Introduction}

Across the globe, the manufacturing industry is of paramount importance because of its role in economic progress and its capacity to generate wealth and employment [1]. The importance of the global manufacturing industry is evident through the value of the manufacturing value addition of 14.17 trillion U.S. dollars in 2018. Nevertheless, despite its significant role, activities undertaken by large scale manufacturing industry are damaging the environment and the society [2]. These activities include high consumption of resources, waste generation and improper waste management. In terms of consumption of resources, the devastating impact of the manufacturing sector can be imagined by the fact that 80 percent of the products that humans consume are disposed of immediately after use. Moreover, 99 percent of the total material flow for consumer goods goes to waste disposal within six months [3].

In terms of waste generation by the manufacturing sector, world estimates of waste generated, such as plastic waste, e-waste and industrial wastes, are alarming. Statistics show the generation of approximately $6300 \mathrm{Tg}$ of plastic waste as of 2015 [4]. Over 50 million metric tons of electronic-waste are generated annually, making e-waste one of the fastest-growing waste categories around the globe. Hence, the manufacturing sector uses large amounts of natural resources in their products and works with inefficient production processes [5,6]. This intensification is leading to global warming, 
climate change and environmental deprivation $[2,7]$. This shows that sustainable performance is not only required to be successful in the global market, but also essential for survival, conservation of the environment and improving the quality of life of society [8]. For that reason, the sustainable performance of organizations presents an open research problem that is attracting attention from both scholars and practitioners [9-11].

In this regard, scholars have considered the effects of different managerial attributes on the sustainable performance of organizations to determine whether managerial characteristics are important determinants of performance $[12,13]$. Past researches based on the upper echelons perspective indicate that manager's age can play a critical role in selecting and implementing strategic decisions that can have a significant impact on the performance of the organization [14]. In this context, scholars have studied various dynamics of the relationship between the manager's age and sustainable corporate performance [15-17]. However, initial research has suggested disagreements among the researchers. Few researchers propose that young managers are more concerned about corporate environmental and social performance while some suggest that young managers as compared to their older counterparts takes steps that reduce the sustainable performance of organizations $[15,18,19]$.

However, in addition to these controversies and conflicting findings, existing studies are silent about how young manager's choices and actions lead to improved sustainable performance [19]. Hence, studies that indicate how and why the manager's age may influence the identification and exploitation of new opportunities for sustainable development that can impact positively on corporate social and environmental performance are rare. This impairs gaining a full understanding of the phenomenon and justifies further investigation. In particular, limited explanation in prior literature regarding how manager's age can influence organizational social and environmental performance and what is the role of sustainable entrepreneurial orientation (SEO) in the relationship between the manager's age and sustainable corporate performance present a good opportunity to determine this association [20]. Therefore, this paper aims to investigate the relationship between manager's age and sustainable corporate performance through SEO based on the insights from strategic leadership characteristics, sustainable entrepreneurial orientation, and sustainable corporate performance literature.

Consequently, we aim to contribute to the existing literature in the following ways. First, we attempt to resolve this apparent conflict regarding the manager's age and sustainable performance relationship [21]. This research contributes by adding an explanation and rationale for the conflicting findings [22]. Second, the present literature shows that the link between the manager's age and SEO has received limited attention [23]. This facet has been grabbed in this study. Third, earlier researches claim that studies on strategic orientation for sustainable entrepreneurship are limited [24]. In this regard, we contribute to determining the relationship of SEO with a manager's age and sustainable corporate performance, and consolidating SEO as a construct of reference in sustainable entrepreneurship research [20]. In particular, we indicate that the ability to identify and exploit new opportunities is associated with youthfulness which in turn positively impacts sustainable performance. Fourth, we contribute to the literature by integrating the upper echelons perspective and dynamic capability approach in explaining the relationship between the manager's age and sustainable corporate performance through SEO. In particular, based on the dynamic capabilities approach, we provide a theoretical proposition of SEO as a dynamic capability and an overall organizational strategic orientation that explains the relationship between manager's age and the sustainable performance of organizations. Fifth, this research is among the earliest that considers the role of SEO for the manager's age-performance relationship in the manufacturing sector. Moreover, it has been argued that existing studies lack relationship models regarding the impact of SEO on sustainable corporate performance in developing country context $[25,26]$. Hence, we extend previous literature by linking the SEO with environmental, social and financial performance in a developing country context which specifies that strategic orientation in emerging economies is critical to obtain substantial benefits in the sustainability context. 
Henceforth, this research is important because it indicates that the manager's youthfulness can bring a difference in the corporate environmental and social performance due to better identification and exploitation of new opportunities for sustainable development. It means that a greater number of young managers in the workforce will increase the probability that overall environmental and social performance will be improved. This provides a reasonable frame of reference for understanding the dynamics of the sustainable performance of the organizations.

\section{Method}

Due to the significance of identifying determinants of sustainable corporate performance and the research objective of figuring out inconsistent findings, proposing how manager's age influences the identification and exploitation of new opportunities for sustainable development and determining the role of sustainable entrepreneurial orientation (SEO) in the relationship between the manager's age and sustainable corporate performance, qualitative and exploratory research was conducted [27]. It was operationalized through a literature review, established on the guidelines given by Torraco [28], who mentioned that systematic review of the literature can be performed to generate new perspectives and knowledge about the selected topic. It is also supported by Seuring and Gold [29] who emphasize that inconsistent research outputs generate the need to conduct literature reviews for effectively evaluating and creating the knowledge base within a research field.

It is vital to mention that methodological rigor is essential in a literature review as required in the existing standards of analytical forms and to ensure replicability, reliability and validity [29]. In this regard, the content analysis technique was carried out in this research to scrutinize the data $[30,31]$ focused on generating the main theme through coding, developing sub-categories and consequently categories.

The procedure selected to carry out this research was based on guidelines given by Tranfield et al., [32]. We began the search on electronic databases like Web of Science, Science Direct, ProQuest, JSTOR, and Google Scholar by using keywords. To conduct an extensive search, keywords such as "sustainable entrepreneurial orientation", "manager's observable characteristics" and "sustainable performance" were used. We targeted research papers published in ranked journals. The custom time range of 1990-2020 was set for this paper. After that, we removed duplicate articles. Next, we scrutinized the journal titles and referred to their scope and ranges to determine whether they were relevant to the scope of the study. After that, we examined the titles of the journal articles and selected papers relevant to the context of this study. Finally, we studied the abstracts of the residual papers and considered their research objectives, questions and approach. As this research attempts to deal with the conflicting findings between manager's age and sustainable performance relationship, the emphasis was on selecting papers that covered the relationship between managerial attributes and sustainable performance and papers that focused on discussing the strategic orientation of sustainable corporate performance. Furthermore, to ensure covering all the relevant papers, we referred to additional sources such as applicable references mentioned in the final set of articles to enrich our justifications about the phenomena. Hence, this closed-circle system was part of the study [20].

\section{Theoretical Background}

\subsection{Manager's Age and Sustainable Corporate Performance}

Age is commonly explained as the length of time for which an individual has been alive. Manager's age is usually discussed in terms of younger and older dimensions [33]. The age of managers affects their perceptions, beliefs and decision-making styles. People of different ages have dissimilar experiences; therefore, they approach the same issue differently. Various studies have shown that as the manager's age progresses, they want to maintain the status quo and reject new ideas. However, as compared to older counterparts, young managers are more enthusiastic and creative, therefore, they welcome new ideas and innovate proactively [34]. 
Sustainable corporate performance is defined as achieving economic returns and meeting shareholders' needs while emphasizing the betterment of the natural environment and society [35]. It is about minimizing the negative effects that the company's activities would have on the environment and the society while improving the quality of life of the community, preserving the environment and taking care of investors' interests $[8,36]$. Three elements of sustainable performance that are derived from the triple bottom line approach include economic, environmental and social. These three dimensions act as elements of a system and all three aspects need to be taken care of to achieve sustainable performance [37].

When it comes to the relationship between manager's age and sustainable corporate performance, prior literature highlights some interesting debate. Various studies have reported that organizations with younger managers perform better in terms of performance due to their propensity to pursue risky strategies and initiate changes in structures, procedures and people as compared to organizations with older managers [38]. Lee et al. [15] supported this claim by suggesting that older managers in large organizations exhibit low social performance. On the contrary, Xu et al. [39] in his study claimed that a manager's age has no significant impact on enterprise performance. On the contrary, based on agency theory, it was advocated that as a manager's environmental knowledge increases with time, older managers perform better in terms of environmental performance than younger managers [40]. These findings were also supported by Trana \& Phama [18] showing that younger managers, in their quest to maximize profits, forgo sustainable practices and performance whereas older managers do not.

\subsection{Sustainable Entrepreneurial Orientation (SEO) and Sustainable Corporate Performance}

In a seminal work on sustainable corporate entrepreneurship, it is defined as a mechanism that focuses on the identification and transformation of opportunities that are linked to sustainable development to new value creation for environment and community while considering costs, risks and uncertainty [26,41]. It is a mechanism that is not limited to starting new ventures, rather it also occurs in established organizations either in the form of new business endeavors or business transformations through strategic renewal [42]. SEO is highly important to implement sustainable corporate entrepreneurship within a business [20]. SEO is defined as an overall strategic orientation that is focused on searching and exploiting opportunities to create future products, processes, and services to preserve the environment and the community and to bring economic and non-economic advantages for the people, the economy and society [43]. It consists of three dimensions, namely innovativeness, proactiveness and risk-taking [44].

Prior literature considers entrepreneurial orientation (EO) and sustainable orientation (SO) as organizational cultural traits $[45,46]$, therefore, SEO is conceptualized as an important constituent of organizational culture that is reflected in business philosophy [47]. It can be understood as an organization's readiness and willingness to undertake innovative, proactive and risky actions for the betterment of the company, society and the environment in which they operate. It is based on the identification of business opportunities, while considering the society, the planet and profit $[47,48]$ and this orientation lets management understand that focusing on the triple bottom line is an investment, an obligation and an opportunity to sustain business in the long run [25].

Theoretical evidence suggests that high levels of innovativeness, proactiveness and risk-taking will enable firms to develop organizational practices that result in zero waste generation, no harmful emissions and use of renewable energy. It will help construct closed-loop production systems and resource-efficient logistics. It will help develop a culture of sensitivity and re-design of business models to turn to a more effective system. Such a mechanism results in improved performance in terms of environmental, social and economic dimensions and enhances the chances of a firm's survival [49].

\subsection{Theories}

Upper echelon theory, stakeholder theory and the dynamic capabilities approach have been used in this study to explain the relationship between constructs. Upper echelon theory, proposed 
by Hambrick and Mason in 1984, highlights the role of characteristics of top managers, such as age, gender, experience and educational background, in determining the strategic choices that organization takes and the outcomes they achieve because of those activities. This theory states that organizational results, strategic choices and performance levels are moderately affected by managerial background characteristics. This implies that organizations with younger managers will have more risk-taking abilities than their older counterparts and they will experience higher growth and performance $[15,50]$. Furthermore, stakeholder theory supports that young managers are highly concerned about social and environmental problems and are more likely to engage in sustainable practices to address these concerns. This is because they are concerned about improving their current and future reputation in the labor market and to obtain the support of the major stakeholders. Hence, younger managers demonstrate improved sustainable performance [40].

Moreover, the dynamic capabilities approach [51] emphasizes that to achieve sustainable performance, organizations need to develop either new resources or capabilities or they should readjust existing resources and capabilities to identify and exploit evolving prospects and opportunities. When organizations will generate dynamic capabilities, they will be able to create, integrate and reconfigure internal and external competencies to deal with the sustainability problems. Therefore, this study advocates that by developing a dynamic capability of SEO, the organization would be able to modify its processes and shift to sustainable operations to be highly productive, effective and efficient [52]. SEO has been studied by scholars in terms of strategic approach [25], in terms of determinants for adopting SEO on individual, organizational and contextual levels [20], the role of environment in SEO [47] and its impact on firm performance [23,53] and customer value co-creation [54]. This denotes the novelty of this proposed model. The conceptual model of this study is illustrated in Figure 1 as follows:

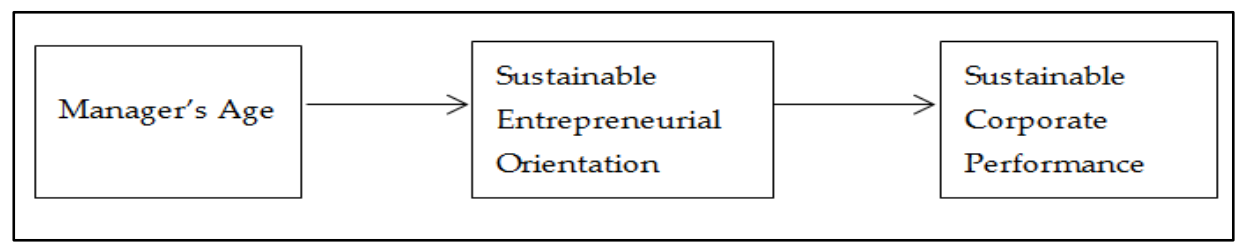

Figure 1. Conceptual framework.

\subsection{Proposition Development: Linking Manager's Age to Sustainable Corporate Performance via SEO}

\subsubsection{Manager's Age and SEO}

The age of a manager represents the level of professional experience they possess, their risk-taking abilities and decision-making styles which in turn impact their behavior choices. Earlier researchers have advocated that an increase in manager's age often reduces the adaptive capacity and cognitive abilities of managers. Generally, it is accepted that young managers, being more passionate, are risk-takers and prefer innovative business decisions. On the other hand, older managers seem to avoid risk, prefer stable business models and are reluctant to shift from traditional strategic choices [55-58].

Moreover, it was found that the age of managers was negatively associated with their capacity to engage in innovative strategies. Hence, managers of higher age in organizations will lead to more conservative strategies and may lose good opportunities available in the market [34,59]. Thus, younger managers, as compared to older ones, will be better able to identify new opportunities in the market through which they can protect the planet and the people. This is also supported by Holtbrügge \& Oberhauser [60] who advocated that the generation in which individuals grow impacts their values and social understandings. Hence, they supported that younger generations are more concerned about environmental and social problems. On the other hand, they showed that individuals from older generations have different worldviews and they have different past professional experiences that mask their vigor and energy to make the world a better place to live. Hence, the age of managers is found to 
be negatively associated with the sustainable entrepreneurial orientation of organizations. Thus, based on these justifications, we propose that:

Proposition one: The younger the manager, the higher the sustainable entrepreneurial orientation of manufacturing organizations.

\subsubsection{SEO and Economic Performance}

Extant literature recognizes the effect of $\mathrm{EO}$ and $\mathrm{SO}$ on business performance, however, the contribution is less clear when we combine both of these orientations in the form of SEO and it may differ with the results that have been demonstrated for EO and SO. Researchers suggest that examining a single strategic orientation cannot fully grasp the strategic relationship between orientations and performance. Therefore, using a multiple strategic orientation view can be more useful. Following this justification, considering SEO as a multiple strategic orientation approach and as a dynamic capability, its link with performance was established [54,61]. In conjunction, it was proposed that SEO significantly impacts financial performance. SEO enhances the implementation of sustainable business practices that minimizes the consumption of resources. This leads to cost efficiency [53].

However, there is mixed evidence about the relationship between SEO and economic performance. Economic performance is linked to profitability and financial returns. It is based on minimizing the operating costs by working efficiently, effectively and productively, and achieving higher returns [62]. Researchers from the other side advocate that there are additional costs associated with sustainable entrepreneurship that constrains the financial impact. This highlights the negative relationship between SEO and economic performance [63]. However, based on the dynamic capabilities approach, it is expected that organizations with SEO are being innovative, proactive and taking risks to make their production processes more efficient, leading to zero wastage and full utilization of resources. This will result in better economic performance $[64,65]$. Based on this justification, we propose that:

Proposition two: The higher the sustainable entrepreneurial orientation in managers, the higher the economic performance of manufacturing organizations.

\subsubsection{SEO and Social Performance}

Social performance assesses the organization's attitude towards society and the community. It emphasizes social development, responsible dealings with consumers, government and investors and creating value for the business by motivating employees [66]. It is about taking care of all the relevant stakeholders apart from just shareholders, including employees and the community. More specifically, it relates to labor laws, human rights, the general public and product concerns [62].

The social dimension of sustainable performance is an under-covered aspect of the literature. Therefore, no conclusive discussions have been present that highlight the relationships between SEO and social performance. However, based on EO, it can be established that $\mathrm{EO}$ enables organizations to create better relationships with stakeholders and improve customer satisfaction and employee safety. It may encourage organizations to act in a socially responsible manner [47]. Moreover, it is advocated that EO helps develops proactiveness capabilities in the organization to appropriately plan and anticipate the developmental needs of employees. It further lets organizations improve their organizational image among the stakeholders. The innovativeness dimension of EO helps develops sustainable products and services that result in improved health and safety of customers. The risk-taking attribute will let organizations avoid products that are affecting the health of society [23,67].

Based on the dynamic capabilities approach, we argue that organizations need to adjust their current stock of resources to deal with substantial social problems. Earlier researches have categorized SEO as a dynamic capability that is required to anticipate, plan and come up with game-changing strategies that are essential to deal with this level of sustainability problems. This will enable organizations to address highly important social challenges [52]. Based on this justification, it is expected that SEO will improve the social performance of the organization. Hence, we propose that: 
Proposition three: The higher the sustainable entrepreneurial orientation in managers, the higher the social performance of manufacturing organizations.

\subsubsection{SEO and Environmental Performance}

Environmental performance is linked with the effects that business activities generate on the natural environment. It is based on the premise that human activities should not destroy the limited resources of land, water and air on earth. The environmental performance involves practices such as cautious use of resources, pollution prevention and waste minimization [64]. Broadly, it takes account of material used, products produced, energy and water use, waste and emissions, compliance with environmental regulations, transportation of products and overall eco-friendly actions that a firm undertakes $[35,68]$.

Extant literature shows that the impact of SEO on environmental performance is less evident [23]. Hence, prior literature raises the question of how sustainable entrepreneurial orientation works in its transition to sustainability. It can be understood by a real-life example of Interface Corporation. Through this orientation, Interface transformed their culture to sustainability by altering their strategy and business models. Instead of selling carpet, they lease carpets. Once the client needs to replace the carpet, Interface takes it back, recycles it and makes use of the recycled components to create new floor coverings. They work on the principles of a truly sustainable organization including zero waste generation, no harmful emissions, use of renewable energy, closed-loop production systems, resource-efficient logistics, a culture of sensitivity and redesign of the business model into a closed-loop system. Interface reshaped its manufacturing system and transformed its business model to achieve environmental performance [69]. In addition to this case, Jiang et al. [53] proposed a positive relationship between SEO and environmental performance. They highlighted that SEO leads to better environmental performance by producing sustainable products, decreasing waste, energy, water and material consumption, and safeguarding employee and customer safety $[20,70]$. Based on this, it is proposed that:

Proposition four: The higher the sustainable entrepreneurial orientation in managers, the higher the environmental performance of manufacturing organizations.

\subsubsection{Manager's Age Diversity, SEO and Sustainable Corporate Performance}

Although the extant literature signifies a direct linkage between the manager's age and sustainable performance [19], the conflicting findings on the nature of the relationship demand further explanation through the missing constructs. Regarding that, scholars argue that young managers are more innovative, and proactive, as compared to their older counterparts. Thus, they tend to take risky actions for the betterment of the company, society and the environment. For example, young managers will do significant investments in sustainability to have sustainable products and processes, they will engage in high search and learning and will be prepared for potential failures [71]. This is because young managers are more concerned about their reputation and to be positively perceived by the stakeholders [40]. Therefore, a manager's youthfulness affects their directional attitude for strategic planning and affects their decision-making processes. This leads to the integration of environmental and social concerns in the business model. This will result in an organization that will be highly flexible and would be able to identify and exploit new opportunities based on the unique combination of resources and capabilities. Hence, this will result in the creation of innovative solutions to preserve the environment [25]. This will include organizational practices that minimize waste generation, lessen harmful emissions and promote the usage of renewable energy. Because of this, it can be said that SEO offers environmental and social solutions by coming up with an overall approach that helps organizations achieve objectives of environmental and social sustainability [72]. As a result, it can be inferred that the manager's age will positively affect the strategic orientation of managers which leads to sustainable corporate performance. 
Based on the justifications provided above, it can be proposed that the manager's age can impact sustainable business performance through SEO. Hence, we posit that:

Proposition five: The relationship between a manager's age and sustainable corporate performance can be mediated through sustainable entrepreneurial orientation of the manager.

\section{Findings}

This research examined the influence of the manager's age on the sustainable performance of organizations in the manufacturing sector with a mediating role of SEO. The findings of this study give strong support to the upper echelons perspective and dynamic capability approach which state that organizational results, strategic choices, and performance levels are moderately affected by managerial background characteristics, as well as being based on identification and exploitation of new opportunities, respectively.

Our findings show that a manager's age can have a positive influence on SEO which supports Proposition 1 of the research. This is in line with the findings of Ma et al. [34], who argued that younger managers, as compared to their older counterparts, identify and engage in capturing new opportunities in the market. Unlike Trana and Phama [18], who claimed that young managers focus on profit maximization and forgo sustainable development, our results strongly favor Holtbrügge and Oberhauser [60] who advocated that young managers are more concerned about environmental and social issues and this affects their strategic choices and performance.

Moreover, we found that higher SEO of managers significantly contributes to economic, social and environmental performance in the manufacturing sector in emerging economies and thus supported Propositions 2, 3 and 4 of the research. Our findings are consistent with Jiang et al. [53] who showed that SEO enhances the implementation of sustainable business practices which minimize the consumption of resources and threats to society, improving environmental and social performance. Furthermore, this leads to cost efficiency due to improved productivity. Hence, our findings strongly support the arguments of Fatoki [23] who suggested that SEO results improved innovativeness, proactiveness and risk-taking abilities of managers, which in turn helps to achieve the sustainable performance of the organization.

Finally, our findings show that SEO can mediate the relationship between a manager's age and sustainable corporate performance which supports Proposition 5 of the research. Our findings support Elmagrhi et al. [40] and Criado-Gomis et al. [25], indicating that a manager's age can have a positive direct influence on SEO and indirect influence on sustainable corporate performance. Hence, based on the findings of this research, we showed that SEO mediates the relationship between manager age and sustainable performance in the manufacturing sector of developing economies.

\section{Discussion and Conclusions}

This research investigated the relationship between a manager's age and sustainable corporate performance through SEO in the manufacturing sector. Extant researches show conflicting findings on the impact of a manager's age on the sustainable performance of organizations [15,19]. Besides, an explanation of how a manager's youthfulness leads to sustainable performance is limited. In this regard, the literature shows that the relationship between a manager's age and SEO, and SEO and sustainable performance, needs attention [25]. Therefore, this study proposed that a manager's youthfulness is positively associated with SEO. It depicts that personal managerial characteristics in terms of a manager's age are thought to play a crucial role in determining the strategic choices the organization makes. This implies that younger managers will be more concerned about environmental and social issues compared to older managers due to their proactiveness, innovativeness and risk-taking abilities. These findings are in line with the arguments of upper echelons theory [50] which suggests the importance of managerial personal characteristics in influencing the strategic choices that the manager makes. 
In addition, based on the dynamic capabilities approach [51], this research proposed that SEO positively impacts on all three dimensions of sustainable performance of organizations. It depicts that SEO allows firms to identify and capture new market opportunities to tackle environmental and social problems and decreases the impact of harmful consequences. This in turn improves their environmental, social and financial performance. This study is supporting the findings of $[53,65]$.

Finally, this study proposed that a manager's youthfulness is positively associated with sustainable corporate performance through SEO. The study argued that organizations with younger managers are more likely to pursue environmentally-friendly strategies and approaches and consequently bring improvement in the social and environmental performance of organizations. Theoretically, this research is supported by the upper echelons perspective and dynamic capability approach which states that a manager's specific attributes, such as age, are important for pursuing sustainable strategies and for implementation of sustainable policies and goals leading to sustainable performance. This is because younger managers can be more considerate about sustainability concerns because of their worldviews to make it a better place to live, not only for the present generations but also for future generations. The research further demonstrates that SEO facilitates the relationship between manager age and sustainable corporate performance which implies that innovativeness, proactiveness and risk-taking attitude to identify and capture new opportunities for the betterment of the society of young managers will generate positive outcomes. Without innovativeness, proactiveness and risk-taking abilities, manufacturing firms will not be good at meeting the customer and market demands of sustainability.

Hence, the role of SEO is highly significant in this regard. It implies that younger managers in the manufacturing sector will be more concerned about setting the organizational strategic direction towards sustainable development objectives. Due to this, they can focus on initiating multiple programs like sustainability training and development programs for the employees, and can bring transformations in internal processes and practices, such as working with sustainable suppliers, using cleaner technologies, efficient processes leading to zero waste discharges and using recyclable materials. Moreover, they can invest heavily to ensure society's wellbeing in all operations and can focus on adopting new ways to improve the health and safety of society. This will help in substantially improving overall customer retention and loyalty, and enhancing the organizational green image. Hence, this is what is needed on an immediate basis to protect the interests of future generations and will serve as a critical factor to address the environmental and social issues prevailing in the manufacturing sector.

\section{Research Implications}

This study has important research implications for the field of sustainable entrepreneurship. First of all, this study enhances the sustainable entrepreneurship literature by presenting SEO as a construct of reference for imminent researches. Secondly, by developing the conceptual linkage between manager age and SEO, this research advocates that the presence of younger managers in the workforce will ensure a smooth transition from traditional manufacturing approaches and it will facilitate the adoption of a more holistic approach of conducting business by undertaking the four $\mathrm{R}$ strategies of reducing, reuse, remanufacture and recycle [73]. Third, by enlightening the conceptual linkage between SEO and sustainable corporate performance, this research shows that organizational strategic orientation which is SEO will help minimize the emission of hazardous substances and waste, and will help reduce the consumption of energy and hazardous materials. This will not only improve the overall environmental situation but will ensure compliance with environmental regulations and standards. Finally, by revealing additional insights on the consequences and outcomes of SEO in developing country context, this will help emerging economies address the problems of high consumption of resources and waste generation, as well as the health and safety and well-being of the society.

This study is subject to certain limitations. First of all, this research pertains to the manufacturing sector so being industry-specific might affect the generalization of the findings. Secondly, there are other managerial attributes such as educational background, managerial exposure, work experience and 
gender roles that are relevant to consider but are not part of this study. Third, this study lacks empirical evidence. Therefore, future researches in this domain can focus on establishing the empirical evidence of the relationship between manager age and sustainable corporate performance through SEO. Moreover, future research can be based on the critical investigation of the effects of each dimension of SEO on sustainable corporate performance in a multi-country context. This will help in determining the most effective configuration of innovativeness, proactiveness and risk-taking dimensions, showing which dimension is highly relevant and contributes most to the sustainable performance of organizations. Next, future researches can determine the drivers of SEO such as the role of leadership commitment and impact of technology drivers. Furthermore, future researches can focus on the role of SEO in the implementation of integrated sustainable practices so that environmentally friendly products can be developed. Furthermore, the role of manager characteristics other than age can be explored in this regard.

Author Contributions: Both authors played significant role in conceptualization and development of the framework. F.A. wrote the original draft. N.R.K. reviewed \& edited the draft and supervised the research. All authors have read and agreed to the published version of the manuscript.

Funding: This research received no external funding.

Conflicts of Interest: The authors declare no conflict of interest.

\section{References}

1. Ong, T.S.; Magsi, H.B.; Burgess, T.F. Organisational culture, environmental management control systems, environmental performance of Pakistani manufacturing industry. Int. J. Product. Perform. Manag. 2019. [CrossRef]

2. Ikram, M.; Zhou, P.; Shah, S.A.A.; Liu, G.Q. Do environmental management systems help improve corporate sustainable development? Evidence from manufacturing companies in Pakistan. J. Clean. Prod. 2019, 226, 628-641. [CrossRef]

3. Caldera, H.T.S.; Desha, C.; Dawes, L. Evaluating the enablers and barriers for successful implementation of sustainable business practice in 'lean' SMEs. J. Clean. Prod. 2019, 218, 575-590. [CrossRef]

4. Saleh, T.A.; Danmaliki, G.I. Polymer Consumption, Environmental Concerns, Possible Disposal Options, and Recycling for Water Treatment. In Sustainable Infrastructure: Breakthroughs in Research and Practice; IGI Global: Pennsylvania, PA, USA, 2020; pp. 691-708.

5. Aboughaly, M.; Gabbar, H.A. Recent Technologies in Electronic-Waste Management. In E-waste Recycling and Management; Springer: Berlin/Heidelberg, Germany, 2020; pp. 63-80.

6. Pavithra, K.G.; Rajan, P.S.S.; Balaji, D.; Gopinath, K.P. Sustainable Electronic-Waste Management: Implications on Environmental and Human Health. In E-waste Recycling and Management; Springer: Berlin/Heidelberg, Germany, 2020; pp. 201-218.

7. Khan, D.; Ullah, A. Testing the relationship between globalization and carbon dioxide emissions in Pakistan: Does environmental Kuznets curve exist? Environ. Sci. Pollut. Res. 2019, 26, 15194-15208. [CrossRef] [PubMed]

8. Orji, I.J. Examining barriers to organizational change for sustainability and drivers of sustainable performance in the metal manufacturing industry. Resour. Conserv. Recycl. 2019, 140, 102-114. [CrossRef]

9. Ghadimi, P.; Wang, C.; Lim, M.K. Sustainable supply chain modeling and analysis: Past debate, present problems and future challenges. Resour. Conserv. Recycl. 2019, 140, 72-84. [CrossRef]

10. Henao, R.; Sarache, W.; Gómez, I. Lean manufacturing and sustainable performance: Trends and future challenges. J. Clean. Prod. 2019, 208, 99-116. [CrossRef]

11. Jawaad, M.; Zafar, S. Improving sustainable development and firm performance in emerging economies by implementing green supply chain activities. Sustain. Dev. 1962, sd.1962. [CrossRef]

12. Kang, J. Unobservable CEO Characteristics and CEO Compensation as Correlated Determinants of CSP. Bus. Soc. 2017, 56, 419-453. [CrossRef]

13. Cho, C.K.; Cho, T.S.; Lee, J. Managerial attributes, consumer proximity, and corporate environmental performance. Corp. Soc. Responsib. Environ. Manag. 2019, 26, 159-169. [CrossRef]

14. Liu, L. Top Management Characteristics, Green Supply Chain Management and Corporate PerformanceModerating Effects of Competition Intensity. J. Hum. Resour. Sustain. Stud. 2019, 7, 55. [CrossRef] 
15. Lee, W.S.; Sun, K.-A.; Moon, J. Application of upper echelon theory for corporate social responsibility dimensions: Evidence from the restaurant industry. J. Qual. Assur. Hosp. Tour. 2018, 19, 387-414. [CrossRef]

16. Huang, S.K. The Impact of CEO Characteristics on Corporate Sustainable Development: CSR Drivers, CSR CEO Characteristics, Hypotheses, Method, Discusssion. Corp. Soc. Responsib. Environ. Manag. 2013, 20, 234-244. [CrossRef]

17. Oh, W.-Y.; Chang, Y.K.; Cheng, Z. When CEO career horizon problems matter for corporate social responsibility: The moderating roles of industry-level discretion and blockholder ownership. J. Bus. Ethics 2016, 133, 279-291. [CrossRef]

18. Trana, N.M.; Phama, B.-N.T. The influence of CEO characteristics on corporate environmental performance of SMEs: Evi-dence from Vietnamese SMEs. Manag. Sci. Lett. 2020, 10, 1671-1682. [CrossRef]

19. Shahab, Y.; Ntim, C.G.; Chen, Y.; Ullah, F.; Li, H.; Ye, Z. Chief executive officer attributes, sustainable performance, environmental performance, and environmental reporting: New insights from upper echelons perspective. Bus. Strategy Environ. 2020, 29, 1-16. [CrossRef]

20. Kraus, S.; Burtscher, J.; Vallaster, C.; Angerer, M. Sustainable Entrepreneurship Orientation: A Reflection on Status-Quo Research on Factors Facilitating Responsible Managerial Practices. Sustainability 2018, 10, 444. [CrossRef]

21. Ladik, D.M.; Stewart, D.W. The contribution continuum. J. Acad. Mark. Sci. 2008, 36, 157-165. [CrossRef]

22. Summers, J.O. Guidelines for conducting research and publishing in marketing: From conceptualization through the review process. In How to Get Published in the Best Marketing Journals; Edward Elgar Publishing: Cheltenham, UK, 2019. [CrossRef]

23. Fatoki, O. Green entrepreneurial orientation and firm performance in South Africa. Entrep. Sustain. Issues 2019, 7, 247-262. [CrossRef]

24. Sarango-Lalangui, P.; Santos, J.; Hormiga, E. The Development of Sustainable Entrepreneurship Research Field. Sustainability 2018, 10, 2005. [CrossRef]

25. Criado-Gomis, A.; Cervera-Taulet, A.; Iniesta-Bonillo, M.-A. Sustainable Entrepreneurial Orientation: A Business Strategic Approach for Sustainable Development. Sustainability 2017, 9, 1667. [CrossRef]

26. Terán-Yépez, E.; Marín-Carrillo, G.M.; Casado-Belmonte, M. del P.; Capobianco-Uriarte, M. de las M. Sustainable entrepreneurship: Review of its evolution and new trends. J. Clean. Prod. 2020, 252, 119742. [CrossRef]

27. De Guimarães, J.C.F.; Dorion, E.C.H.; Severo, E.A. Antecedents, mediators and consequences of sustainable operations: A framework for analysis of the manufacturing industry. Benchmarking Int. J. 2019. [CrossRef]

28. Torraco, R.J. Writing Integrative Literature Reviews: Guidelines and Examples. Hum. Resour. Dev. Rev. 2005, 4, 356-367. [CrossRef]

29. Seuring, S.; Gold, S. Conducting content-analysis based literature reviews in supply chain management. Supply Chain Manag. Int. J. 2012, 17, 544-555. [CrossRef]

30. Duriau, V.J.; Reger, R.K.; Pfarrer, M.D. A Content Analysis of the Content Analysis Literature in Organization Studies: Research Themes, Data Sources, and Methodological Refinements. Organ. Res. Methods 2007, 10, 5-34. [CrossRef]

31. Mayring, P. Qualitative content analysis: Theoretical background and procedures. In Approaches to qualitative research in mathematics education; Springer: Berlin/Heidelberg, Germany, 2015; pp. 365-380.

32. Tranfield, D.; Denyer, D.; Smart, P. Towards a Methodology for Developing Evidence-Informed Management Knowledge by Means of Systematic Review. Br. J. Manag. 2003, 14, 207-222. [CrossRef]

33. Tanikawa, T.; Kim, S.; Jung, Y. Top management team diversity and firm performance: Exploring a function of age. Team Perform. Manag. Int. J. 2017, 23, 156-170. [CrossRef]

34. Ma, Y.; Zhang, Q.; Yin, Q.; Wang, B. The Influence of Top Managers on Environmental Information Disclosure: The Moderating Effect of Company's Environmental Performance. Int. J. Environ. Res. Public. Health 2019, 16, 1167. [CrossRef]

35. Huo, B.; Gu, M.; Wang, Z. Green or lean? A supply chain approach to sustainable performance. J. Clean. Prod. 2019, 216, 152-166. [CrossRef]

36. Svensson, G.; Padin, C. Industry note: Sustainable development requires economic, social and environmental sustainability: A business perspective. Int. J. Agric. Innov. Technol. Glob. 2019.

37. Khurana, S.; Haleem, A.; Mannan, B. Determinants for integration of sustainability with innovation for Indian manufacturing enterprises: Empirical evidence in MSMEs. J. Clean. Prod. 2019, 229, 374-386. [CrossRef] 
38. Wang, F.; Cheng, Z.; Keung, C.; Reisner, A. Impact of manager characteristics on corporate environmental behavior at heavy-polluting firms in Shaanxi, China. J. Clean. Prod. 2015, 108, 707-715. [CrossRef]

39. Xu, J.; Yun, K.; Yan, F.; Jang, P.; Kim, J.; Pang, C. A Study on the Effect of TMT Characteristics and Vertical Dyad Similarity on Enterprise Achievements. Sustainability 2019, 11, 2913. [CrossRef]

40. Elmagrhi, M.H.; Ntim, C.G.; Elamer, A.A.; Zhang, Q. A study of environmental policies and regulations, governance structures, and environmental performance: The role of female directors. Bus. Strategy Environ. 2019, 28, 206-220. [CrossRef]

41. Cohen, B.; Winn, M.I. Market imperfections, opportunity and sustainable entrepreneurship. J. Bus. Ventur. 2007, 22, 29-49. [CrossRef]

42. Gast, J.; Gundolf, K.; Cesinger, B. Doing business in a green way: A systematic review of the ecological sustainability entrepreneurship literature and future research directions. J. Clean. Prod. 2017, 147, 44-56. [CrossRef]

43. Shepherd, D.A.; Patzelt, H. The New Field of Sustainable Entrepreneurship: Studying Entrepreneurial Action Linking "What Is to Be Sustained" With “What Is to Be Developed". Entrep. Theory Pract. 2011, 35, 137-163. [CrossRef]

44. Syrjä, P.; Puumalainen, K.; Sjögrén, H.; Soininen, J.; Durst, S. Entrepreneurial orientation in firms with a social mission-A mixed-methods approach. Cogent Bus. Manag. 2019, 6. [CrossRef]

45. Alvarez, S.A.; Busenitz, L.W. The entrepreneurship of resource-based theory. J. Manag. 2001, 27, 755-775. [CrossRef]

46. Crittenden, V.L.; Crittenden, W.F.; Ferrell, L.K.; Ferrell, O.C.; Pinney, C.C. Market-oriented sustainability: A conceptual framework and propositions. J. Acad. Mark. Sci. 2011, 39, 71-85. [CrossRef]

47. Hernández-Perlines, F.; Ibarra Cisneros, M. The Role of Environment in Sustainable Entrepreneurial Orientation. The Case of Family Firms. Sustainability 2018, 10, 2037. [CrossRef]

48. Thananusak, T. Science Mapping of the Knowledge Base on Sustainable Entrepreneurship, 1996-2019. Sustainability 2019, 11, 3565. [CrossRef]

49. Konys, A. Towards Sustainable Entrepreneurship Holistic Construct. Sustainability 2019, 11, 6749. [CrossRef]

50. Hambrick, D.C. Upper Echelons Theory: An update; Academy of Management Briarcliff Manor: New York, NY, USA, 2007; p. 10510. [CrossRef]

51. Teece, D.; Pisano, G. The Dynamic Capabilities of Firms: An Introduction. Ind. Corp. Change 1994, 3, 537-556. [CrossRef]

52. Yu, W.; Jacobs, M.A.; Chavez, R.; Yang, J. Dynamism, disruption orientation, and resilience in the supply chain and the impacts on financial performance: A dynamic capabilities perspective. Int. J. Prod. Econ. 2019, 218, 352-362. [CrossRef]

53. Jiang, W.; Chai, H.; Shao, J.; Feng, T. Green entrepreneurial orientation for enhancing firm performance: A dynamic capability perspective. J. Clean. Prod. 2018, 198, 1311-1323. [CrossRef]

54. Criado-Gomis, A.; Iniesta-Bonillo, M.Á.; Cervera-Taulet, A.; Ribeiro-Soriano, D. Customer functional value creation through a sustainable entrepreneurial orientation approach. Econ. Res.-Ekon. Istraživanja 2019, 1-18. [CrossRef]

55. Chan, D.; Berger, R.; Man, T.W.Y. The impact of managerial characteristics on business strategies under the environmental change: An investigation of the Israeli diamond industry. J. Small Bus. Entrep. 2019, 1-26. [CrossRef]

56. Gryshova, I.; Petrova, M.; Tepavicharova, M.; Diachenko, A.P.; Gutsul, T. A model for selection of a management team to ensure the sustainability and development of the business organizations. Entrep. Sustain. Issues 2019, 7, 690-703. [CrossRef]

57. Muñoz-Pascual, L.; Galende, J.; Curado, C. Human Resource Management Contributions to Knowledge Sharing for a Sustainability-Oriented Performance: A Mixed Methods Approach. Sustainability 2019, $12,161$. [CrossRef]

58. Wiersema, M.F.; Bantel, K.A. Top management team demography and corporate strategic change. Acad. Manage. J. 1992, 35, 91-121.

59. Tihanyi, L.; Ellstrand, A.E.; Daily, C.M.; Dalton, D.R. Composition of the top management team and firm international diversification. J. Manag. 2000, 26, 1157-1177. [CrossRef]

60. Holtbrügge, D.; Oberhauser, M. CSR orientation of future top managers in India. J. Indian Bus. Res. 2019, 11, 162-178. [CrossRef] 
61. Criado-Gomis, A.; Iniesta-Bonillo, M.Á.; Cervera-Taulet, A. Sustainable entrepreneurial orientation within an intrapreneurial context: Effects on business performance. Int. Entrep. Manag. J. 2018, 14, 295-308. [CrossRef]

62. Hussain, N.; Rigoni, U.; Orij, R.P. Corporate Governance and Sustainability Performance: Analysis of Triple Bottom Line Performance. J. Bus. Ethics 2018, 149, 411-432. [CrossRef]

63. Shrivastava, M.; Tamvada, J.P. Which green matters for whom? Greening and firm performance across age and size distribution of firms. Small Bus. Econ. 2019, 52, 951-968. [CrossRef]

64. Masocha, R.; Fatoki, O. The Impact of Coercive Pressures on Sustainability Practices of Small Businesses in South Africa. Sustainability 2018, 10, 3032. [CrossRef]

65. Prado, G.F.; Piekarski, C.M.; Luz, L.M.; Souza, J.T.; Salvador, R.; Francisco, A.C. Sustainable development and economic performance: Gaps and trends for future research. Sustain. Dev. 2019, sd.1982. [CrossRef]

66. Martinez-Conesa, I.; Soto-Acosta, P.; Palacios-Manzano, M. Corporate social responsibility and its effect on innovation and firm performance: An empirical research in SMEs. J. Clean. Prod. 2017, 142, 2374-2383. [CrossRef]

67. Mullens, D. Entrepreneurial orientation and sustainability initiatives in family firms. J. Glob. Responsib. 2018, 9, 160-178. [CrossRef]

68. Roscoe, S.; Subramanian, N.; Jabbour, C.J.; Chong, T. Green human resource management and the enablers of green organisational culture: Enhancing a firm's environmental performance for sustainable development. Bus. Strategy Environ. 2019. [CrossRef]

69. Miles, M.P.; Munilla, L.S.; Darroch, J. Sustainable corporate entrepreneurship. Int. Entrep. Manag. J. 2009, 5, 65-76. [CrossRef]

70. Tseng, C.-H.; Chang, K.-H.; Chen, H.-W. Strategic Orientation, Environmental Innovation Capability, and Environmental Sustainability Performance: The Case of Taiwanese Suppliers. Sustainability 2019, 11, 1127. [CrossRef]

71. Filser, M.; Eggers, F. Entrepreneurial orientation and firm performance: A comparative study of Austria, Liechtenstein and Switzerland. S. Afr. J. Bus. Manag. 2014, 45, 55-65. [CrossRef]

72. Sung, C.; Park, J. Sustainability Orientation and Entrepreneurship Orientation: Is There a Tradeoff Relationship between Them? Sustainability 2018, 10, 379. [CrossRef]

73. Beekaroo, D.; Callychurn, D.S.; Hurreeram, D.K. Developing a sustainability index for Mauritian manufacturing companies. Ecol. Indic. 2019, 96, 250-257. [CrossRef]

(C) 2020 by the authors. Licensee MDPI, Basel, Switzerland. This article is an open access article distributed under the terms and conditions of the Creative Commons Attribution (CC BY) license (http://creativecommons.org/licenses/by/4.0/). 